The History of Dermatology. By William Allen Pusey. Size $5 \frac{3}{4} \times$ 9. Pp. xviii + 224. 32 Illustrations. Price I7s. $6 d$. Publishers : Messrs. Baillière, Tindall \& Cox.

AвоUт eighteen months ago I had the pleasure of reviewing a short text-book on dermatology in this journal, the title of which I felt tempted to alter to "Dermatology without tears." This excellent little book I am glad to have seen in the hands of a good many medical students, and I would like to suggest that Dr. Pusey's book be acquired as a companion volume for those students and practitioners who have been stimulated by Dr. Roxburgh to take an intelligent interest in dermatology, and indeed to all British dermatologists.

It is, of course, obvious that a taste for, say music, may be cultivated without any knowledge of the history of the subject, but nevertheless the majority of enthusiastic listeners do learn something about its history. It may perhaps be difficult to look upon dermatology in the same light, but strange though the fact may appear there are some who have an enthusiasm for the subject and who find their interest doubled by some knowledge of the early literature of the subject.

Dr. Pusey's work is the only history of dermatology in English. It is a summary, but an excellently written and most efficient summary. The story is complete enough to include most of the significant details from the earliest period to the present century. He has wisely taken pains to trace the relationship between the history of dermatology and that of medicine in general, and this has given the subject a living interest which would be lacking in a bare chronological account of dermatology alone. There is at the end of the book an historical index compiled by Dr. Herbert Rattner from the enormous number of data used in the preparation of the book. This index is valuable material for reference to the original descriptions of almost every dermatoses and a number of general diseases, including of course syphilis and leprosy, as well as mycological, pathological and bacteriological researches connected with these diseases.

Dr. Pusey has adopted the plan of dividing the story into periods, beginning at 3000 B.C. and ending in the present century. From I750 onwards each period is dealt with in a separate chapter and each country concerned in the advance in progress in dermatology is dealt with in order. Great Britain receives its full share of recognition for the services rendered to Dermatology by Robert Willam, Thomas Bateman, Erasmus Wilson, Tilbury Fox, Huxley, Addison, Grill, and, in more recent times, Jonathan Hutchinson, Colcott Fox, Radcliffe Crocker and others.

Dr. Pusey finds cause for regret in the fact that as in England progress in American dermatology has been largely and is still a question of individual effort, and that Continental Europe has the advantage 


\section{REVIEW OF BOOK}

over the English-speaking countries for the study of the multitudinous problems of the subject through organised effort.

It is impossible to attempt a summary of the contents of this book ; I am only able to say that it may be safely recommended to all those who have acquired an interest in an absorbing subject and who would like to have their interest enhanced.

G. B. D. 